\title{
Methodology of statistical study of the chemical composition of by-products of coal mining to assess their suitability as materials for reclamation
}

\section{Introduction}

Waste rock strata accompanying the coal seams are increasingly treated not as waste but as a source of mineral resources for economic use and the production of waste material is an integral part of both the process of mining and preparation of the raw material. The content of sulfur and other elements in the rock material accompanying the coal seams varies significantly (e.g. Klojzy-Karczmarczyk 2003; Góralczyk and Baic 2009; Korban 2011; Michalska and Białecka 2012; Rosik-Dulewska 2012; Bzowski and Dawidowski 2013; Klojzy-Karczmarczyk and Mazurek 2014; Strugała et al. 2014; Dziok et al. 2015; Jabłońska-Czapla et al. 2015; Kosa and Kicińska 2016; Klojzy-Karczmarczyk et al. 2016a, 2016b, 2016c). These contents are often elevated in relation to the limit values set for inert mining waste. Furthermore, an increase of the leaching of sulfur compounds from the waste material with increasing time of its residence in the environment has been proven. The search for new solutions in the field of management of by-products from coal mining and the improvement of existing ones, results in the need to minimize the amount of waste, while increasing the weight of the product used in various economic processes. However, this is a complex issue both in terms of the regulations relating both to the quality of the waste rock material, and

* D.Sc. Eng., Assoc. Prof. AGH University of Science and Technology, Krakow, Poland; e-mail: mucha@geol.agh.edu.pl

** Ph.D. Eng., *** M.Sc. Eng., Mineral and Energy Economy Research Institute, Polish Academy of Sciences, Krakow, Poland; e-mail: beatakk@min-pan.krakow.pl; jan@min-pan.krakow.pl 
with regard to potential threats to the soil and water environment. In the long term, the degradation of sulfides towards the production of sulfates is possible. Sulfates - as easily soluble - may pose a threat to the environment. Due to the variation of sulfur content in the waste material and the ability to activate sulfates with time, the low content of sulfides in the base material destined for reclamation by filling the pit is therefore important.

Studies conducted and described in the earlier works involving the authors (Klojzy-Karczmarczyk et al. 2016a, b, c) indicate the possibility of the use of mining waste from the Janina Coal Mine (Upper Silesian Coal Basin, Poland, TAURON Wydobycie S.A.) or products based on gangue (aggregates) for the technical reclamation. It is essential for this process to obtain a material with low total sulfur. A characteristic feature of the waste material from coal mining is a strong relationship binding the size of the fraction of material with sulfur content. With the increase in the size of the fractions the sulfur content decreases nonlinearly (Klojzy-Karczmarczyk et al. 2016c). Similar regularities can be expected with regard to the content of heavy metals. Therefore, in the case of exceedance of the regulatory limits for inert waste in the rock material remaining after coal preparation, it is logical and rational to reduce the excessive content of harmful components by eliminating the finest fractions by screening of the original material.

The conclusions presented in earlier works (Klojzy-Karczmarczyk et al. 2016a, b, c) are based on the results of laboratory tests. In order to verify, it is desirable to conduct statistical analysis. This preliminary analysis of selected quality parameters of the studied waste and aggregates is the subject of a separate publication involving the authors (Klojzy-Karczmarczyk et al. 2016a, b). The conducted analysis requires, however, a detailed consideration of the use of different statistical methods. In the presented work, the problem of determining the maximum size of the fraction of material needed for screening or (what amounts to the same thing) for determining the minimum fraction of the rock material meeting the limits and therefore safe as aggregate for filling the post-mining pits was undertaken. This task was achieved by using classical statistical analysis including a different methodical approach to solve the problem. Further in the article a case study of rocks that are the product of mining and preparation of coal in the Janina Coal Mine for which three statistical methods were proposed for determining the lower limit of the fraction of material that guarantees, with a low risk of error, to not exceed the allowable limit (maximum) of the content of harmful ingredients treated as reference values is presented. The application of advanced methods of statistical analysis for this purpose may facilitate the design of technological processes, leading to obtaining industrial quantities of high quality, appropriately graded reclamation material used for the environmentally safe backfilling of the open pits during the technical reclamation works phase.

Both statistical and geostatistical methods were often used to evaluate the content and description of the spatial distribution of contaminating components such as e.g. sulfur (Probierz and Marcisz 2001; Mucha and Wasilewska 2005; Mucha et al. 2008; Kokesz 2010; Marcisz 2013; Mucha and Wasilewska-Błaszczyk 2015), phosphorus (Morga 2007; Marcisz 2014) or chlorine (Marcisz and Sobolewski 2015) in coal seams of the Upper Silesian Coal Basin. The results of the analyses obtained for deposits "in situ", however, do not give gro- 
unds to forecast the content of the contaminating components in the waste materials generated during coal preparation due to the variable height of the operating wicket and, consequently, due to the size of gangue ripping which is difficult to predict. A reliable assessment of the fraction of rock material which meets the requirements of relevant standards requires direct sampling of coal mining waste.

\section{Conditions of use of waste rock material from the Janina Coal Mine for reclamation of pits in relation to quality standards}

The materials that are a side effect of mining production (both mining waste and aggregates), produced during the exploitation and processing of coal are characterized by the presence of impurities of various substances and elements harmful to the soil and water environment. The use of such waste and products thereof, e.g. aggregates, for the reclamation of brownfield sites (including open-pit quarries), is subject to a number of restrictions under the applicable laws in the field of waste management and environmental protection. The basic requirement for the use thereof for the purpose of reclamation is an obligation to meet different standards (operating limits of contaminants) in the waste/products in order to protect the soil and water environment from pollution at the point of storage. In this respect, there are currently several legal acts in force relating both to waste and to the maximum levels of allowable levels of contaminants potentially introduced with leachate into the environment (Klojzy-Karczmarczyk and Mazurek 2015; Kicki and Sobczyk ed. 2016). The need to ensure a sufficiently low content of sulfur and heavy metals referred to as the total content in both the material and the volume of elution of a given component, that may be a result of influence of atmospheric conditions on the waste masses arises, among others from the above regulations.

A characteristic feature of the coal mining waste is a variation of polluting impurities content, depending on the grain size of the waste material. As follows from the conducted detailed research of team of authors B. Klojzy-Karczmarczyk, J. Mazurek and K. Paw (2016c) for the material from the Janina Coal Mine, a majority of impurities in the material is found in the smallest range of grain fractions with diameters of $0-20 / 30 \mathrm{~mm}$. As the lower limit of the particle size increases, the total sulfur content, and most of the analyzed metals and metalloids, is decreased. Above a certain minimum particle diameter, the tested material is characterized by good parameters, satisfying legal requirements, including the criteria for inert waste for the soil and water environment. The analysis of the sulfur content in all the fractions separated from the 16 collected raw (primary) samples revealed a high variation of this parameter. The highest sulfur content was measured in the finest fraction with a diameter of $0-6 \mathrm{~mm}$, where the calculated average sulfur content reaches nearly $5 \%$. However the calculated average sulfur content in the modified sample has a value of less than $1 \%$, above the $35 \mathrm{~mm}$ grain diameter. Given the mass share of each grain fractions and their measured sulfur content, it can be assumed that the aggregates with a grain diameter 
greater than $20 \mathrm{~mm}$ may be a perspective material for filling reclaimed open-pit mines. The objective of the proposed statistical analysis is to confirm that value and to search for the lower grain boundary above which the sulfur content in the sample is less than the adopted $1 \%$.

In the laboratory so-called secondary (modified) samples were prepared by an rejection of the fraction below $10 \mathrm{~mm}$, and below $20 \mathrm{~mm}$ and re-mixing of the samples while preserving their mass shares, and the detailed results as summarized in the work cited above. Studies of the content of the total and leachable forms of particular components were conducted. The total content of individual elements varies for the secondary samples produced by a combination of fractions of $10-200 \mathrm{~mm}(>10 \mathrm{~mm})$ and of the secondary samples of fraction $20-200 \mathrm{~mm}(>20 \mathrm{~mm})$. Fractions with a particle size of $>200 \mathrm{~mm}$ were not found in this case. Most often higher contents of particular elements are observed in the secondary samples resulting from the combination of fractions of $10-200 \mathrm{~mm}$. Isolated exceedances of the total sulfur content were found while maintaining the average value at a level appropriate for inert mining waste. The results obtained in the contaminants leaching test indicate that the tested modified samples (after the rejection of fine fractions) will not introduce abnormal amounts of the analyzed elements or sulfates. Only in aqueous extracts of the secondary samples may one observe frequent exceedances of the specific electrolytic conductivity and in two cases, an increase in chlorides content. It can be assumed that there are reasonable grounds to obtain a stable product, safe for the environment in the process of reclamation, characterized by an average sulfur content of not more than $1 \%$, which is a sufficient condition for the simultaneous presence of other favorable parameters of the analyzed aggregates, such as a sufficiently high rate of neutralization potential and low content of other contaminants shown in the conducted 1:10 leaching tests (batch test).

\section{Primary material for statistical surveys}

The basis of the statistical analysis were the results of a special experimental sampling of rock produced during the mining and preparation of coal at the Janina Coal Mine (Klojzy-Karczmarczyk et al. 2016b, c). Of the 16 raw samples collected from the conveyor, hereinafter referred to as the primary samples, with an average weight of about $200 \mathrm{~kg}$ each, 15 fractions were separated $(0-6,6-8,8-10,10-16,16-20,20-25,25-30,30-35,35-40$, $40-50,50-60,60-80,80-120,120-200$ and $>200 \mathrm{~mm}$ (fraction $>200 \mathrm{~mm}$ was actually not found) for which the Laboratory at the Janina Coal Mine determined the total sulfur content $\left(\mathrm{S}_{\mathrm{t}}{ }^{\mathrm{d}}\right)$ in a dry matter $(\mathrm{DM})$ using the high temperature method. On the basis of these measurements, the sulfur content in the primary samples was calculated using a weighted average for mass fraction and then in the conventional secondary samples generated from primary samples through the elimination of the subsequent fractions starting from the finest. For example, the symbol $\mathrm{S}_{\mathrm{t}}{ }^{\mathrm{d}} 10+[\mathrm{mm}]$ represents the total sulfur content in the dry matter in a secondary sample, produced from the primary sample after the elimination of the fraction of less than $10 \mathrm{~mm}$, i.e., the content of sulfur in the rock material with a fraction of $>10 \mathrm{~mm}$ 
(in this case 10-200 $\mathrm{mm}$ ). Thus formed data sets were used to determine the upper limits of the confidence interval for the sulfur content and for testing the hypothesis of equality of the average sulfur content to the reference content (the maximum allowed) in various variants of secondary samples. The allowed (reference) value of the sulfur content was assumed at 1\%, in compliance with the Regulation of the Minister of Environment of July 15, 2011 on the criteria for assigning mining waste as inert waste (Journal of Laws of 2011, No. 175, item 1048). The sulfur content in the individual fractions of the combined material from all 16 primary samples was calculated and, on this basis, subsequently, the sulfur content in the rock material above the lower limits of each of the 15 fractions was calculated. The data set created this way was used to construct a model of the relationships between the lower limit of the fraction and the sulfur content in the rock material above this limit.

Data sets with contents of 11 elements (As, $\mathrm{Cd}, \mathrm{Co}, \mathrm{Cr}, \mathrm{Cu}, \mathrm{Hg}, \mathrm{Mo}, \mathrm{Ni}, \mathrm{Pb}, \mathrm{V}, \mathrm{Zn}$ ) were derived from the 13 secondary samples and included the determination of the total content of metals and metalloids by spectrophotometric method, conducted at the MEERI PAS laboratory and ICP OES method in the hydrogeochemical laboratory of the AGH University. Analyses were conducted in only two variants of rock material fractions of secondary samples: $10-200 \mathrm{~mm}(>10 \mathrm{~mm})$ and $20-200 \mathrm{~mm}(>20 \mathrm{~mm})$. Therefore, with respect to the metals and metalloids, the statistical analysis was restricted to an estimation of the upper limits of the confidence interval for the average content in the indicated fractions and to comparing them with the limits allowed for inert mining waste (Journal of Laws of 2011, No. 175, item 1048).

\section{Methodology of statistical research}

The exclusive use of estimates of the average content of components potentially contaminating the post-mining waste (sulfur and other elements) as a criterion for determining the lower limits of the fraction of rock material that meets the requirements of the limit values is insufficient and risky due to the generally high variability of the contents of the contaminating components between different batches of waste. A more appropriate and safer approach is to set the lower limit of the material's fraction wherein with the predetermined but low probability of error, the content of contaminants does not exceed the allowable limit (reference value). To solve this task at least three different statistical approaches presented below with regard to sulfur content may be used.

\section{Method 1}

In this method, the calculation the of sulfur content was used in the subsequent series of secondary samples, obtained by the successive elimination of fractions from the primary samples from the finest fraction to the thickest. For each series of samples the upper, guaranteed average contents of the potentially contaminating component were determined. The guaranteed average content of this component is understood as such content $\left(\mathrm{x}_{\mathrm{u}}\right)$ for which the probability that the actual average content (m) will be higher is small and does 
not exceed, for example, $\alpha=0.05$ or $\alpha=0.01$ i.e. $\mathrm{P}\left(\mathrm{m}>\mathrm{x}_{\mathrm{u}}\right)=\alpha$. The series with the highest average guaranteed sulfur content which complies with the limits imposed for inert mining waste $(<1 \% \mathrm{~S})$ defines the lower limit of the fraction of the rock material deemed as safe for reclamation. Assuming a normal distribution of the feature in a population, the guaranteed value $\left(\mathrm{x}_{\mathrm{u}}\right)$ is calculated with the formula (1):

$$
\mathrm{x}_{\mathrm{u}}=\overline{\mathrm{x}}+\mathrm{t}_{1-\alpha} \frac{\mathrm{s}}{\sqrt{\mathrm{n}}}
$$
$\Leftrightarrow \overline{\mathrm{x}} \quad-$ the average (arithmetic mean) sulfur content in a given series of secondary samples,
n - statistical sample size,
$\mathrm{s} \quad$ - standard deviation in the sulfur content in a series of secondary samples,
$t_{1-\alpha}-$ quantile of t-Student's distribution of degree $(1-\alpha)$ for $(n-1)$ degrees of freedom.

For data sets for which the correct determination of the upper guaranteed values based on the above formula is substantively unreasonable because of the failure to comply with the assumptions of its applicability, one can use the approximate, non-parametric method referred to in English literature as bootstrapping. This is for example the case if the statistical sample is small (counts less than 30 observations) and the distribution of probability is drastically deviated from normal. In this method, the guaranteed values (upper bootstrap bound) are determined through the multiple drawing of lots with a replacement. With a statistical n-element sample (e.g. contents of the component determined for $\mathrm{n}$ secondary samples) one can conduct multiple draws of $\mathrm{k}$ independent random samples ( $\mathrm{k}$ should be large, optionally in Statgraphics it is assumed at $\mathrm{k}=500$ ), then for each value the arithmetic mean is determined. After alignment of the arithmetic means in ascending order for the assumed probability level of $\mathrm{P}=1-\alpha$, one determines the upper limit of the confidence interval (upper boot strap bound).

\section{Method 2}

As in Method 1, this approach also requires estimating the sulfur content in the secondary samples after subsequent eliminations of fractions in the primary samples starting from the finest and involves testing a null hypothesis $\left(\mathrm{H}_{0}\right)$ about the equality of the average content of the potentially contaminating component with the reference (limit) value against the alternative hypothesis $\left(\mathrm{H}_{1}\right)$, that the average is smaller than the reference value. In the case of a small statistical sample and assuming normal distribution of the feature in the general population (justified by the results of testing the normality of distribution, e.g. using the Shapiro-Wilk test most recommended in recent years), the $t$ statistic checking the null hypothesis is as follows:

$$
\mathrm{t}=\frac{\overline{\mathrm{x}}-\mathrm{m}_{0}}{\mathrm{~s}} \sqrt{\mathrm{n}}
$$


$\Leftrightarrow \overline{\mathrm{x}}-$ the average (arithmetic mean) sulfur content in a given series of secondary samples,

$\mathrm{s}$ - standard deviation,

n - statistical sample size (number of secondary samples in the series),

$\mathrm{m}_{0}-$ hypothetical average value in the general population (assuming reference, allowable sulfur content).

Statistic $\mathrm{t}$ - assuming the truth of the null hypothesis $\left(\mathrm{H}_{0}\right)$ - has a $\mathrm{t}$-Student distribution with $n-1$ degrees of freedom. Unlike the traditional, classical hypothesis testing of statistical hypotheses, hypothesis testing using computer software is carried out on the basis of the so-called test probability (Sokołowski 2004) represented by the P-value (or p-value). It can be defined as a boundary, the lowest level at which the observed value of the test statistic leads to a rejection of the null hypothesis. Rejection of the null hypothesis occurs when the $\mathrm{P}$-value $\leq \alpha$, and there is no reason to reject it when the $\mathrm{P}$-value $>\alpha$.

\section{Method 3}

The method involves determining the model of the relationships between the average contents of the potentially contaminating components above consecutive boundaries of the rock material fractions and boundaries of these fractions and the upper limits of the confidence intervals for the designated model. The lower limit of the fraction of rock material that meets the limit values must be considered one for which the upper limit of the confidence interval for the regression model is closest to the limit but does not exceed it. The upper limit of the confidence interval $\left(\mathrm{Y}_{\mathrm{u}, \mathrm{x}, \alpha}\right)$ for the assumed level of significance $\alpha$ and for any value of the independent variable $\mathrm{x}$ is determined by the general formula:

$$
\mathrm{Y}_{\mathrm{u}, \mathrm{x}, \alpha}=\hat{\mathrm{Y}}_{\mathrm{x}}+\mathrm{t}_{\alpha, \mathrm{n}-2} \mathrm{~s}\left(\hat{\mathrm{y}}_{\mathrm{x}}\right)
$$

$\Leftrightarrow \hat{Y}_{\mathrm{X}} \quad-$ the value of the dependent variable (contaminating component) read from the regression model for the fixed value of the independent variable $\mathrm{x}$ (lower limit of the fraction),

$\mathrm{t}_{\alpha, \mathrm{n}-2}-$ quantile of the t-Student distribution of degree $(1-\alpha)$ for $\mathrm{df}=\mathrm{n}-2$ degrees of freedom,

$s\left(\hat{y}_{x}\right)-$ the standard error of the estimate of the expected value of feature $Y$ at the set value of feature $\mathrm{X}=\mathrm{x}$. 


\section{Separation of the lower fraction of rock material that meets allowable requirements - the Janina Coal Mine case study}

For the waste material from the Janina coal mine the lowest fraction of grain size above which with relatively high probability the sulfur content is sufficiently low (below $1 \%$ ) was determined. Furthermore, for the secondary samples prepared by screening it was determined whether with relatively high probability there will be no exceeding of the permissible limit values for the analyzed metals and metalloids, set for the inert mining waste. The analysis in both cases is reduced to the use of the same statistical tools. In practice, the most important task is to develop a methodology sufficiently accurate for the determination of the key parameters (e.g. the percentage content of sulfur) in the mass of waste/aggregate in industrial quantities, as a function of their grain size, estimated on the basis of the study of the parameters of a limited, statistically significant random sample derived from a given batch of waste/aggregate.

Given the wide range of sulfur content indications, only for that element the procedure of determining the lower limits of the rock material fraction that meets the imposed limits was conducted using the three statistical methods described in the preceding section. In the case of the content of 11 selected metals and metalloids, the analysis was limited to verification using method 1 whether the upper guaranteed metal contents in fractions $10-200 \mathrm{~mm}$ (in the tables and figures $10+[\mathrm{mm}])$ and $20-200 \mathrm{~mm}(20+[\mathrm{mm}])$ do not exceed the specific limit (maximum) values set by relevant regulations. In both cases, calculations were conducted using the statistical software STATGRAPHICS (2014).

\subsection{Sulfur content studies}

The statistics of sulfur content in the primary samples for the full range of grain sizes (Table 1), indicates a relatively high variability of this parameter with a variation coefficient of just over $40 \%$. The standardized skewness and kurtosis coefficients, as well as the Shapiro-Wilk normality test results give no reason to reject the hypothesis of normal distribution of the sulfur content in the primary samples.

The lower limit of the confidence interval (1.48\%) for the probability level $\mathrm{P}=0.99$, determined due to the statistically small sample using t-Student's distribution, is significantly higher than the reference, allowable sulfur content of $1 \%$. This confirms the desirability of research regarding the contents of sulfur in the rock material remaining after the elimination of subsequent fractions starting with the finest.

The key for solving the posed task are the secondary samples produced from the primary samples after the removal of fractions of material with a diameter of $<10 \mathrm{~mm},<16 \mathrm{~mm}$, $<20 \mathrm{~mm}$, and $<25 \mathrm{~mm}$, for which the statistics of sulfur content and study results are shown in Table 2. As with the primary samples, the Shapiro-Wilk's test does not give grounds to 
Table 1. Summary statistics for total content of sulfur $\left(\mathrm{S}_{\mathrm{t}}{ }^{\mathrm{d}}[\%]\right)$ in 16 primary samples

Tabela 1. Statystyka zawartości siarki całkowitej w stanie suchym $\left(\mathrm{S}_{\mathrm{t}}{ }^{\mathrm{d}}[\%]\right)$ oznaczonej w 16 próbach pierwotnych)

\begin{tabular}{|l|c|}
\hline \multicolumn{1}{|c|}{ Statistics } & Values \\
\hline Count & 16 \\
\hline Average [\%] & 2.16 \\
\hline Coeff. of variation [\%] & 43 \\
\hline Minimum/Maximum [\%] & $0.43 / 3.88$ \\
\hline Stnd. Skewness/Kurtosis & $0.42 /-0.18$ \\
\hline Shapiro-Wilk test of normality (P-value) & 0.86 \\
\hline Confidence interval for mean (P = 0.99) [\%] & $1.48 ; 2.84$ \\
\hline
\end{tabular}

Table 2. Statistics of the total sulfur contents in distinguished 16 secondary samples for 4 variants of lower fraction limits

Tabela 2. Statystyka zawartości siarki całkowitej w 16 próbach wtórnych dla 4 wariantów dolnych granic frakcji

\begin{tabular}{|c|c|c|c|c|}
\hline \multirow{2}{*}{ Statistics of sulfur content } & \multicolumn{4}{|c|}{ Fraction } \\
\hline & $10+[\mathrm{mm}]$ & $16+[\mathrm{mm}]$ & $20+[\mathrm{mm}]$ & $25+[\mathrm{mm}]$ \\
\hline Arithmetic mean [\%] & 1.06 & 0.93 & 0.85 & 0.78 \\
\hline Coefficient of variation [\%] & 38 & 38 & 39 & 43 \\
\hline Minimum/Maximum [\%] & $0.29 / 1.66$ & $0.28 / 1.44$ & $0.27 / 1.32$ & $0.23 / 1.19$ \\
\hline Shapiro-Wilk test of normality (P-value) & 0.85 & 0.62 & 0.43 & 0.08 \\
\hline $\begin{array}{l}\text { Upper confidence bound for } \mathrm{S}_{\mathrm{t}}{ }^{\mathrm{d}} \text { mean content [\%] } \\
\text { (probability level } \mathrm{P}=0.95 \text { ) }\end{array}$ & 1.23 & 1.08 & 0.99 & 0.93 \\
\hline $\begin{array}{l}\text { Upper confidence bound for } \mathrm{S}_{\mathrm{t}}{ }^{\mathrm{d}} \text { mean content [\%] } \\
\text { (probability level } \mathrm{P}=0.99 \text { ) }\end{array}$ & 1.31 & 1.16 & 1.06 & 0.997 \\
\hline $\begin{array}{l}\text { t-test: P-value } \\
\text { Null hypothesis: mean } \mathrm{S}_{\mathrm{t}}{ }^{\mathrm{d}}=1.0[\%] \\
\text { Alternative hypothesis: mean } \operatorname{Std}<1[\%]\end{array}$ & 0.73 & 0.216 & 0.043 & 0.009 \\
\hline $\begin{array}{l}\text { Upper confidence bound for } \mathrm{S}_{\mathrm{t}}{ }^{\mathrm{d}} \text { contents } \\
\text { [\%] predicted from fitted model for } \mathrm{P}=0.95\end{array}$ & 1.15 & 0.99 & 0.91 & 0.83 \\
\hline $\begin{array}{l}\text { Upper confidence bound for } \mathrm{S}_{\mathrm{t}}{ }^{\mathrm{d}} \text { contents [\%] } \\
\text { predicted from fitted model for } \mathrm{P}=0.99 \text { (Fig. 1) }\end{array}$ & 1.18 & 1.01 & 0.93 & 0.84 \\
\hline
\end{tabular}


reject the hypothesis of normal distribution of the sulfur content (at the significance level of $\alpha=0.05$ ). The average sulfur content in the secondary samples is less than $1 \%$, starting from the fraction of $>16 \mathrm{~mm}$. With the risk of error of less than 0.05 , the upper limit of the confidence interval for the average sulfur content does not exceed $1 \%$ in the fraction with a particle diameter of $>20 \mathrm{~mm}$ and the risk of error is not greater than 0.01 for the fraction of $>25 \mathrm{~mm}$. The same conclusions may be drawn from the results of t-Student's test, the alternative hypothesis on the sulfur content in the rock being less than $1 \%$ for the 0.05 level of significance should be accepted for the fraction $>20 \mathrm{~mm}$ and at a significance level of 0.01 for the fraction of $>25 \mathrm{~mm}$.

Plot of Fitted Model and Upper Confidence Bound $\mathrm{Std}+=\exp \left(\mathrm{a}+\mathrm{b}^{*} \operatorname{sqrt}(\right.$ Fraction $\left.)\right)$

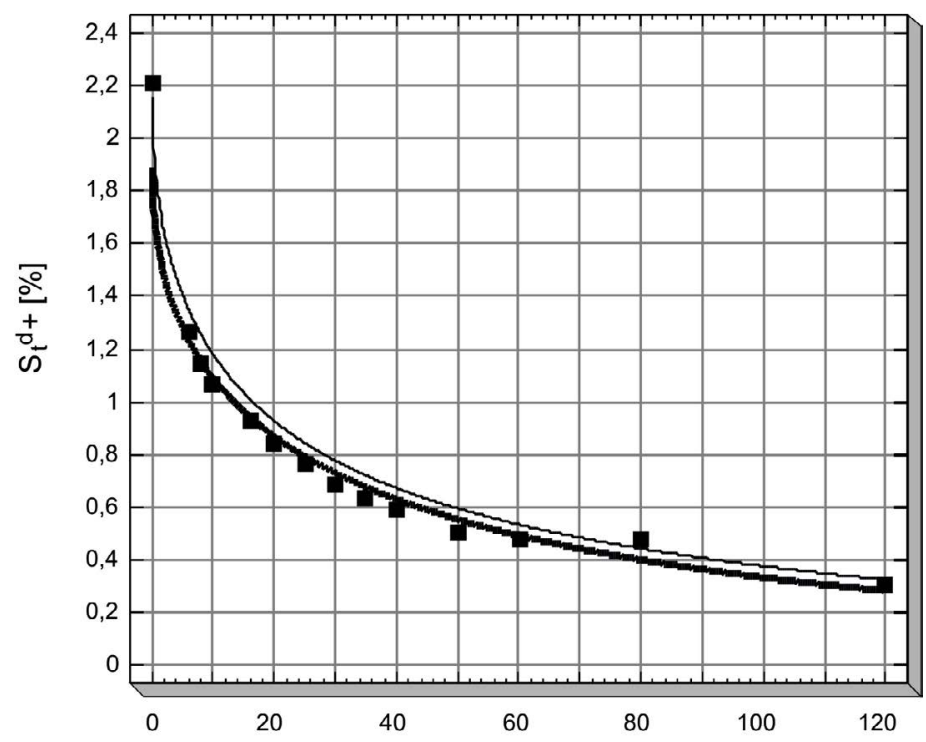

Fraction (lower limit) [mm]

Fig. 1. The graph of the best fitted model (thick line) of empirical dependence between the sulfur content and the lower fraction limit of material (thin line - upper confidence bound for probability level $\mathrm{P}=0.99$ ). Explanations: equation of non-linear regression

$$
\mathrm{S}_{\mathrm{t}}{ }^{\mathrm{d}}+[\%]=\mathrm{e}^{0.636-0.174 \sqrt{\mathrm{Fr}[\mathrm{mm}]}}
$$

P-value $=0.000$, coefficient of determination $\mathrm{R}^{2}=97.3 \%$

$\left(\mathrm{S}_{\mathrm{t}} \mathrm{d}_{+}-\right.$the sulfur content in the rock material above lower limit of fraction $\left.\mathrm{Fr}\right)$

Rys. 1. Wykres najlepiej dopasowanego modelu (linia gruba) zależności empirycznej między zawartością siarki i dolną granicą frakcji materiału skalnego

(linia cienka - górna granica przedziału ufności dla poziomu prawdopodobieństwa $\mathrm{P}=0,99$ ). Objaśnienia: równanie funkcji regresji nieliniowej:

$$
\mathrm{S}_{\mathrm{t}}^{\mathrm{d}}+[\%]=\mathrm{e}^{0,636-0,174 \sqrt{\mathrm{Fr}[\mathrm{mm}]}}
$$

P-wartość $=0,000$, współczynnik determinacji $\mathrm{R}^{2}=97,3 \%$

$\left(\mathrm{S}_{\mathrm{t}} \mathrm{d}_{+}-\right.$zawartość siarki w materiale skalnym powyżej dolnej granicy frakcji Fr) 
Only slightly different, but milder results of determining the lower limits of the fraction of rock "safe" from the point of view of sulfur content are obtained from the non-linear regression function binding the lower limits of the fraction with the contents of sulfur in the rock material above those boundaries (Fig. 1). It should be noted that against the background of a wide variety of regression models proposed by the statistical software STATGRAPHICS, the chosen model is the best in the sense of the goodness of approximation based on empirical dependency as evidenced by the high value of the coefficient of determination $\left(\mathrm{R}^{2}=97.3 \%\right)$ and very high statistical significance $(\mathrm{P}-\mathrm{value}=0.000)$. The lower limits of the fraction above which the sulfur content does not exceed $1 \%$, read from the upper limit of the confidence interval amount to $16 \mathrm{~mm}$ for the probability level $\mathrm{P}=0.95$ and $20 \mathrm{~mm}$ for the probability level $\mathrm{P}=0.99$ (Table 2).

Analyzing and generalizing the results of applications of the three proposed statistical methods, it can be safely assumed that the fraction of $>20 \mathrm{~mm}$ and very safely the fraction of $>25 \mathrm{~mm}$ guarantee that the contents of total sulfur in a dry matter in the rock material that is the product of coal preparation do not exceed the permissible, reference value of $1 \%$. Similar but slightly stricter results were also obtained for the preliminary tests conducted on the waste material from the Janina coal mine based on an analysis of 8 primary samples (Klojzy-Karczmarczyk et al. 2016a). It was then concluded that the fraction of $>20 \mathrm{~mm}$ with high safety and the fraction of $>30 \mathrm{~mm}$ with very high safety ensures the sulfur content in the rock material below $1 \%$. They are caused by higher coefficients of variation for the sulfur content of approximately $50-60 \%$ and may be associated with small sample size. It cannot be ruled out that collecting additional raw samples to achieve a statistically high sample size ( $>30$ observations) will - through statistical analysis - allow for lowering the lower limit of the fraction of rock material safe from the point of view of the content of sulfur.

\subsection{Studies of selected other elements}

The examination of the contents of elements ( $\mathrm{As}, \mathrm{Cd}, \mathrm{Co}, \mathrm{Cr}, \mathrm{Cu}, \mathrm{Hg}, \mathrm{Mo}, \mathrm{Ni}, \mathrm{Pb}, \mathrm{V}, \mathrm{Zn}$ ) in the waste rock material was limited to determining the upper limits of the confidence interval for the average content (guaranteed content) for two fractions: $>10 \mathrm{~mm}(10-200 \mathrm{~mm})$ and $>20 \mathrm{~mm}(20-200 \mathrm{~mm})$. The limit of determination was assumed for the calculation of the average value in the case of very low contents. Statistics for the total content of 11 elements prepared on the basis of 13 secondary samples are summarized in Table 3.

Against the background of the allowable (reference) content limits, the average contents of the analyzed components are usually much lower than the reference values as early as for the fraction of $>10 \mathrm{~mm}$. Only the average nickel content exceeds $50 \%$ of the reference value. With the exception of copper and molybdenum, during the transition from the fraction of $>10 \mathrm{~mm}$ to $>20 \mathrm{~mm}$ there is a decline in the average content of other elements. Due to the partial non-fulfillment of the condition of the normal distribution of metals content for the 
Table 3. Statistics of element contents for fractions 10-200 $\mathrm{mm}$ and 20-200 $\mathrm{mm}$ of 13 secondary samples

Tabela 3. Statystyka zawartości pierwiastków we frakcjach 10-200 mm oraz 20-200 mm dla 13 prób wtórnych

\begin{tabular}{|c|c|c|c|c|c|c|c|c|c|}
\hline \multirow{2}{*}{$\begin{array}{c}\text { Component } \\
{[\mathrm{mg} / \mathrm{kg}]} \\
\mathrm{DM}\end{array}$} & \multirow{2}{*}{$\begin{array}{l}\text { Reference } \\
{[\mathrm{mg} / \mathrm{kg}]^{*}}\end{array}$} & \multicolumn{4}{|c|}{ Fraction $10+[\mathrm{mm}]$} & \multicolumn{4}{|c|}{ Fraction $20+[\mathrm{mm}]$} \\
\hline & & Mean & $\begin{array}{c}\text { Upper } \\
\text { bound } \\
\mathrm{CL}=0.99\end{array}$ & $\begin{array}{c}\text { Bootstrap } \\
\text { Bounds } \\
\text { CL }=0.99\end{array}$ & $\begin{array}{c}\text { Shapiro- } \\
\text { Wilk Test } \\
\text {-value }\end{array}$ & Mean & $\begin{array}{c}\text { Upper } \\
\text { bound } \\
\text { CL }=0.99\end{array}$ & $\begin{array}{l}\text { Bootstrap } \\
\text { Bounds } \\
\mathrm{CL}=0.95\end{array}$ & $\begin{array}{c}\text { Shapiro- } \\
\text { Wilk Test } \\
\text { P-value }\end{array}$ \\
\hline As & 20 & $\begin{array}{c}1.31 \\
(6.6 \%)\end{array}$ & $\begin{array}{c}2.12 \\
(10.6 \%)\end{array}$ & $\begin{array}{c}2.00 \\
(10.0 \%)\end{array}$ & 0.040 & $\begin{array}{c}1.04 \\
(5.2 \%)\end{array}$ & $\begin{array}{c}1.69 \\
(8.5 \%)\end{array}$ & $\begin{array}{c}1.64 \\
(8.2 \%)\end{array}$ & 0.021 \\
\hline $\mathrm{Cd}$ & 5 & $\begin{array}{c}0.071 \\
(1.4 \%)\end{array}$ & $\begin{array}{c}0.112 \\
(2.2 \%)\end{array}$ & $\begin{array}{c}0.109 \\
(2.2 \%)\end{array}$ & 0.005 & $\begin{array}{c}0.041 \\
(0.8 \%)\end{array}$ & $\begin{array}{c}0.060 \\
(1.2 \%)\end{array}$ & $\begin{array}{c}0.060 \\
(1.2 \%)\end{array}$ & 0.001 \\
\hline $\mathrm{Co}$ & 30 & $\begin{array}{c}5.12 \\
(17.1 \%)\end{array}$ & $\begin{array}{c}6.30 \\
(21.0 \%)\end{array}$ & $\begin{array}{c}6.03 \\
(20.1 \%)\end{array}$ & 0.057 & $\begin{array}{c}4.61 \\
(15.4 \%)\end{array}$ & $\begin{array}{c}5.40 \\
(18.0 \%)\end{array}$ & $\begin{array}{c}5.24 \\
(17.5 \%)\end{array}$ & 0.627 \\
\hline $\mathrm{Cr}$ & 150 & $\begin{array}{c}32.3 \\
(21.5 \%)\end{array}$ & $\begin{array}{c}38.2 \\
(25.5 \%)\end{array}$ & $\begin{array}{c}37.4 \\
(24.9 \%)\end{array}$ & 0.364 & $\begin{array}{c}31.3 \\
(20.9 \%)\end{array}$ & $\begin{array}{c}34.9 \\
(23.3 \%)\end{array}$ & $\begin{array}{c}33.9 \\
(22.6 \%)\end{array}$ & 0.443 \\
\hline $\mathrm{Cu}$ & 100 & $\begin{array}{c}16.3 \\
(16.3 \%)\end{array}$ & $\begin{array}{c}19.5 \\
(19.5 \%)\end{array}$ & $\begin{array}{c}19.2 \\
(19.2 \%)\end{array}$ & 0.108 & $\begin{array}{c}17.7 \\
(17.7 \%)\end{array}$ & $\begin{array}{c}22.9 \\
(22.9 \%)\end{array}$ & $\begin{array}{c}22.7 \\
(22.7 \%)\end{array}$ & 0.188 \\
\hline $\mathrm{Hg}$ & 3 & $\begin{array}{c}0.015 \\
(0.5 \%)\end{array}$ & $\begin{array}{c}0.021 \\
(0.7 \%)\end{array}$ & $\begin{array}{c}0.019 \\
(0.6 \%)\end{array}$ & 0.039 & $\begin{array}{c}0.008 \\
(0.3 \%)\end{array}$ & $\begin{array}{c}0.010 \\
(0.3 \%)\end{array}$ & $\begin{array}{c}0.010 \\
(0.3 \%)\end{array}$ & 0.000 \\
\hline Mo & 10 & $\begin{array}{c}0.536 \\
(5.4 \%)\end{array}$ & $\begin{array}{c}0.701 \\
(7.0 \%)\end{array}$ & $\begin{array}{c}0.686 \\
(6.9 \%)\end{array}$ & 0.005 & $\begin{array}{c}0.624 \\
(6.2 \%)\end{array}$ & $\begin{array}{c}0.991 \\
(9.9 \%)\end{array}$ & $\begin{array}{c}0.939 \\
(9.4 \%)\end{array}$ & 0.001 \\
\hline $\mathrm{Ni}$ & 50 & $\begin{array}{c}28.9 \\
(57.8 \%)\end{array}$ & $\begin{array}{c}34.9 \\
(69.8 \%)\end{array}$ & $\begin{array}{c}34.1 \\
(68.2 \%)\end{array}$ & 0.027 & $\begin{array}{c}26.3 \\
(52.6 \%)\end{array}$ & $\begin{array}{c}31.3 \\
(62.6 \%)\end{array}$ & $\begin{array}{c}30.6 \\
(61.2 \%)\end{array}$ & 0.207 \\
\hline $\mathrm{Pb}$ & 100 & $\begin{array}{c}31.0 \\
(31.0 \%)\end{array}$ & $\begin{array}{c}49.9 \\
(49.9 \%)\end{array}$ & $\begin{array}{c}50.4 \\
(50.4 \%)\end{array}$ & 0.000 & $\begin{array}{c}20.0 \\
(20.0 \%)\end{array}$ & $\begin{array}{c}26.5 \\
(26.5 \%)\end{array}$ & $\begin{array}{c}25.2 \\
(25.2 \%)\end{array}$ & 0.473 \\
\hline $\mathrm{V}$ & 350 & $\begin{array}{c}48.1 \\
(13.7 \%)\end{array}$ & $\begin{array}{c}56.6 \\
(16.2 \%)\end{array}$ & $\begin{array}{c}55.6 \\
(15.9 \%)\end{array}$ & 0.537 & $\begin{array}{c}46.7 \\
(13.3 \%)\end{array}$ & $\begin{array}{c}52.0 \\
(14.9 \%)\end{array}$ & $\begin{array}{c}50.5 \\
(14.4 \%)\end{array}$ & 0.567 \\
\hline $\mathrm{Zn}$ & 500 & $\begin{array}{c}79.8 \\
(16.0 \%)\end{array}$ & $\begin{array}{c}100.4 \\
(20.1 \%)\end{array}$ & $\begin{array}{c}96.0 \\
(19.2 \%)\end{array}$ & 0.693 & $\begin{array}{c}66.0 \\
(13.2 \%)\end{array}$ & $\begin{array}{c}83.9 \\
(16.8 \%)\end{array}$ & $\begin{array}{c}82.9 \\
(16.6 \%)\end{array}$ & 0.054 \\
\hline
\end{tabular}

Explanation: ( ) - percentage contents of metals and metalloids in the reference (maximum) values, CL-confidence level

* Regulation of the Minister of Environment of July 15, 2011 on the criteria for assigning mining waste as inert waste (Journal of Laws of 2011, No. 175, item 1048); Regulation of the Minister of Environment of 9 September 2002 on the criteria for soil and ground quality (Journal of Laws of 2002, No. 165, item 1359). 
significance level $\alpha=0.05$ (P-value $<0.05$ ), to determine the upper limits of the confidence interval (guaranteed content) the method of bootstrapping was applied in addition to the classical method. Both methods give similar results. For the fraction of 10-200 mm, only guaranteed contents of lead and nickel reach $50-70 \%$ of the allowable values. For other metals the upper limits of the confidence intervals do not exceed $50 \%$ of the allowable value and are generally much lower than that. An unambiguous conclusion may be drawn that the suitability of the rock material accompanying the coal seams in the Janina coal mine is determined by the sulfur content. Due to the decidedly low contents of metals and metalloids in the 1:10 water extracts from the secondary samples, no statistical analysis was conducted for such material.

\section{Summary and Conclusions}

Statistical methods are an effective tool for assessing the suitability of waste from the preparation of coal as a material for reclamation when one has reliable sampling results. For this purpose, the following can be used in particular: the evaluation of guaranteed (the maximum for a given degree of probability) contents of the polluting components, the results of statistical hypotheses testing and analysis of correlation and regression.

The applied statistical methods produce results very proximate to each other. Slight differences may be due to slightly differing masses of the raw samples collected during the sampling and due to their small number. For this reason, it is necessary to periodically verify the obtained results through conducting of a control sampling of the products of coal preparation. In the presented case study of the waste from the Janina Coal Mine the determined total contents of 11 elements (not including sulfur) in the secondary samples for the fraction of 10-200 $\mathrm{mm}$ and $20-200 \mathrm{~mm}$ showed they are lower than the allowable limits specified by relevant legal regulations.

For these fractions the exceedance of the limit values by the sulfur content, however, is highly likely. Thus, the essential criterion for the suitability of the material for the reclamation shall be the total sulfur content in a dry matter. Due to the non-linear reduction in the sulfur content with the increasing fraction size of the rock material, the simplest method of obtaining the material ,safe" for reclamation is screening and separating the finest fractions. The determination of the lower limits of the material fraction that meets the environmental requirements provided in relevant regulations should be conducted using statistical methods based on the results of reliable sampling of rock material remaining after coal preparation. In the presented case study for the Janina coal mine, based on the results of a statistically small sample ( $<30$ observations), rock material fraction of $>20 \mathrm{~mm}$ may be considered as safe for the purposes of reclamation, and the material fraction of $>25 \mathrm{~mm}$ as very safe. One cannot exclude, however, that this limit can be reduced (e.g. to $16 \mathrm{~mm}$ ) for a supplementary sampling with an increased number of observations until reaching a statistically large sample ( $>30$ observations). 
It can be assumed that the proposed methodology of the statistical studies can be successfully applied to the analysis of waste material from other coal mines as well as for mines of other mineral resources.

The authors would like to express their gratitude to TAURON Wydobycie S.A. in Jaworzno for providing data and enabling the conduct of this work.

The publication has been partially realized within the framework of the statutory research of MEERI PAS and AGH (No. 11.11.140.320) which was funded by TAURON Wydobycie S.A.

\section{REFERENCES}

Bzowski, Z. and Dawidowski, A. 2013. Monitoring właściwości fizykochemicznych odpadów wydobywczych pochodzących z kopalni węgla kamiennego LW „Bogdanka”. Zeszyty Naukowe nr 149 Uniwersytetu Zielonogórskiego, Inżynieria środowiska No. 29, pp. 87-96 (in Polish).

Dziok i in. 2015 - Dziok, T., Strugała, A., Rozwadowski, A., Macherzyński, M. and Ziomber, S. 2015. Rtęć w odpadach z procesu wzbogacania węgli kamiennych. Gospodarka Surowcami Mineralnymi-Mineral Resources Management Vol. 31(1), pp. 107-122 (in Polish).

Góralczyk, S. and Baic, I. 2009. Odpady z górnictwa węgla kamiennego i możliwości ich gospodarczego wykorzystania. Polityka Energetyczna - Energy Policy Journal Vol. 12(2/2), pp. 145-157 (in Polish).

Jabłońska-Czapla i in. 2015 - Jabłońska-Czapla, M., Rosik-Dulewska, C., Szopa, S. and Zerzucha, P. 2015. Research into the metal/metalloid movements in soil and groundwater in the areas surrounding the coal waste dump Hałda Ruda (Upper Silesia, Poland). Rocznik Ochrona Środowiska Vol. 17, pp. 367-395.

Journal of Laws of 2002, No. 165, item 1359. Rozporządzenie Ministra Środowiska z dnia 9 września 2002 roku w sprawie standardów jakości gleby oraz standardów jakości ziemi (in Polish).

Journal of Laws of 2011, No. 175, item 1048. Rozporządzenie Ministra Środowiska z dnia 15 lipca 2011r. w sprawie kryteriów zaliczania odpadów wydobywczych do odpadów obojętnych (in Polish).

Kicki, J. and Sobczyk, E.J. 2016. Prawne, techniczne, ekonomiczne i środowiskowe aspekty gospodarki skała płonna w kopalniach węgla kamiennego. Kraków: Wyd. IGSMiE PAN, 185 pp. (in Polish).

Klojzy-Karczmarczyk i in. 2016a - Klojzy-Karczmarczyk B., Mazurek J., Staszczak J., Mucha J. and Paw K. 2016. Ocena możliwości rekultywacji odkrywkowych wyrobisk poeksploatacyjnych z wykorzystaniem kruszyw ze skał towarzyszących pokładom węgla kamiennego na przykładzie ZG Janina. Górnictwo Odkrywkowe No 5 , pp. 23-33 (in Polish).

Klojzy-Karczmarczyk, B. 2003. Zastosowanie odpadów energetycznych w ograniczaniu transportu zanieczyszczeń ze składowisk odpadów górniczych. Studia, Rozprawy, Monografie No 117, Kraków: Wyd. IGSMiE PAN, 113 pp. (in Polish)

Klojzy-Karczmarczyk i in. 2016b - Klojzy-Karczmarczyk, B., Mazurek, J. and Mucha, J. 2016. Sulfur as a parameter in the suitability assessment of gangue from coal mining for reclamation of opencast excavation, taking into the requirements regarding protection of the soil. E3S Web of Conferences 10, 00036 (published on line: e3s-conferences.org).

Klojzy-Karczmarczyk i in. 2016c - Klojzy-Karczmarczyk, B., Mazurek, J. and Paw, K. 2016. Możliwości zagospodarowania kruszyw i odpadów wydobywczych górnictwa węgla kamiennego ZG Janina w procesach rekultywacji wyrobisk odkrywkowych. Gospodarka Surowcami Mineralnymi-Mineral Resources Management Vol. 32(3), pp. 111-134 (in Polish).

Klojzy-Karczmarczyk, B. and Mazurek, J. 2015. Uwarunkowania prawne i środowiskowe rekultywacji wyrobisk odkrywkowych z wykorzystaniem odpadów górnictwa węgla kamiennego lub produktów na bazie skały płonnej. Zeszyty Naukowe Instytutu Gospodarki Surowcami Mineralnymi i Energia PAN No. 90, pp. 67-78 (in Polish). 
Kokesz, Z. 2010. Geostatystyczna analiza zmienności zawartości siarki w wybranych pokładach węgla GZW. Gospodarka Surowcami Mineralnymi - Mineral Resources Management Vol. 26(3), pp. 95-110 (in Polish).

Korban, Z. 2011. Problem odpadów wydobywczych i oddziaływania ich na środowisko, na przykładzie zwałowiska Nr 5A/W-1 KWK „X”. Górnictwo i Geologia No 6(1), pp. 109-120 (in Polish).

Kosa, B. and Kicińska, A. 2016. Coal from the waste disposal site of the Siersza mine (Trzebinia, Poland) and its properties as a possible alternative fuel. E3S Web of Conferences 10, 00039 (published on line: e3s-conferences.org).

Marcisz, M. 2013. Zawartość siarki całkowitej w złożach monokliny Zofiówki (SW część Górnośląskiego Zagłębia Węglowego). Gospodarka Surowcami Mineralnymi - Mineral Resources Management Vol. 29(3), p. 61 (in Polish).

Marcisz, M. 2014. Zawartość fosforu w złożach monokliny Zofiówki (SW część Górnośląskiego Zagłębia Węglowego). Gospodarka Surowcami Mineralnymi-Mineral Resources Management Vol. 30(2), pp. 67-84 (in Polish).

Marcisz, M. and Sobolewski, A. 2015. Chlorine content in bituminous coal of „Pniówek” deposit from SW part of Upper Silesian Coal Basin. Gospodarka Surowcami Mineralnymi - Mineral Resources Management Vol. 31(1), pp. 95-106

Michalska, A. and Białecka, B. 2012. Zawartość rtęci w węglu i odpadach górniczych. Prace Naukowe GIG-Górnictwo i Środowisko No. 3/12, pp. 73-87 (in Polish).

Morga, R. 2007. Struktura zmienności zawartości fosforu w eksploatowanych pokładach węgla kamiennego KWK Pniówek. Gospodarka Surowcami Mineralnymi - Mineral Resources Management Vol. 23(1), pp. 29-48 (in Polish).

Mucha i in. 2008 - Mucha, J., Wasilewska, M., Nieć, M., Saługa, P. and Sobczyk, E.J. 2008. Ryzyko inwestycji w górnictwie węgla kamiennego jako funkcja dokładności oszacowań parametrów złożowych. Gospodarka Surowcami Mineralnymi - Mineral Resources Management Vol. 24 (2/4), pp. 161-173 (in Polish).

Mucha, J. and Wasilewska, M. 2005. Dokładność interpolacji zawartości siarki i popiołu w wybranych pokładach węgla kamiennego GZW. Gospodarka Surowcami Mineralnymi-Mineral Resources Management Vol. 21(1), pp. 5-21 (in Polish)

Mucha, J. and Wasilewska-Błaszczyk, M. 2015. Interpolation and Sampling Errors of the Ash and Sulphur Contents in Selected Polish Bituminous Coal Deposit (Upper Silesian Coal Basin-USCB). Archives of Mining Sciences Vol. 60(3), pp. 791-806.

Probierz, K. and Marcisz, M. 2001. Zmiany zawartości popiołu i siarki w węglach z pokładu 415/2 w cyklu produkcyjnym KWK Szczygłowice. Zeszyty Naukowe Politechniki Śląskiej, Seria Górnictwo Issue 249, pp. 135 (in Polish).

Rosik-Dulewska, C. 2012. Podstawy gospodarki odpadami. Wyd. V, Warszawa: Wyd. Naukowe PWN, 379 pp. (in Polish).

Sokołowski, A. 2004. O niewłaściwym stosowaniu metod statystycznych. StatSoft Polska Sp. z o.o. [Online] Available at: www.statsoft.pl [Accessed: 1.10.2016] (in Polish)

STATGRAPHICS® Centurion XVII User Manual 2014, Statpoint Technologies, Inc.

Strugała i in. 2014 - Strugała, A., Makowska, D., Bytnar, K. and Rozwadowska, T. 2014. Analiza zawartości wybranych pierwiastków krytycznych w odpadach z procesu wzbogacania węgla kamiennego. Polityka Energetyczna-Energy Policy Journal Vol. 17(4), pp. 77-88 (in Polish). 


\section{METODYKA STATYSTYCZNEGO BADANIA SKLADU CHEMICZNEGO \\ PRODUKTÓW UBOCZNYCH WYDOBYCIA WEGLA KAMIENNEGO DLA OCENY ICH PRZYDATNOŚCI, JAKO MATERIALÓW REKULTYWACYJNYCH}

Słowa kluczowe

rekultywacja, kruszywa, odpady wydobywcze, siarka, metale i metaloidy, analiza statystyczna

\section{Streszczenie}

Wyniki badań przedstawione we wcześniejszych pracach z udziałem autorów (Klojzy-Karczmarczyk i in. 2016a, b, c) wskazują na możliwość wykorzystania odpadów wydobywczych ZG Janina (Górnośląskie Zagłębie Węglowe, Polska, TAURON Wydobycie S.A.) lub produktów (kruszyw) wytwarzanych na bazie skały płonnej do celów rekultywacji technicznej. Istotne jest pozyskanie do tego procesu materiału o niskiej zawartości siarki całkowitej, przy czym wykazano, że najlepsze parametry jakościowe uzyskuje się dla materiału poddanego modyfikacji poprzez odrzucenie frakcji drobnych. W prezentowanej pracy, przy zastosowaniu analizy statystycznej, wyznaczono dolną granicę frakcji materiału, w którym z założonym ale małym prawdopodobieństwem popełnienia błędu, zawartości składników zanieczyszczających (siarki oraz innych pierwiastków) nie przekroczą dopuszczalnej, granicznej zawartości (wartości referencyjnej). Do rozwiązania tego zadania zastosowano 3 różne metody statystyczne: oceny gwarantowanych (maksymalnych dla założonego poziomu prawdopodobieństwa) zawartości składników zanieczyszczających, wyniki testowania hipotez statystycznych oraz analizę korelacji i regresji. Zastosowane metody statystyczne dają wyniki bardzo zbliżone do siebie. W przedstawionym studium przypadku dla ZG Janina opartym na wynikach statystycznie małej próby ( $<30$ obserwacji) za bezpieczny dla celów rekultywacji można uznać materiał skalny o frakcji $>20 \mathrm{~mm}$, natomiast za bardzo bezpieczny materiał skalny o frakcji $>25 \mathrm{~mm}$. Nie można wykluczyć jednak, że granica ta może być obniżona do średnicy $16 \mathrm{~mm}$. Analiza zawartości 11 pierwiastków (As, $\mathrm{Cd}, \mathrm{Co}, \mathrm{Cr}, \mathrm{Cu}, \mathrm{Hg}, \mathrm{Mo}, \mathrm{Ni}, \mathrm{Pb}, \mathrm{V}, \mathrm{Zn}$ ) oznaczonych w formie całkowitej w próbach wtórnych dla frakcji 10-200 mm (obecności frakcji >200 mm nie stwierdzono) wykazała, że są one niższe od zawartości dopuszczalnych określonych odpowiednimi rozporządzeniami. Dla tej frakcji przekroczenie wartości granicznych przez zawartość siarki jest jednak wysoce prawdopodobne. $Z$ tego względu podstawowym kryterium decydującym o przydatności materiału odpadowego dla celów rekultywacji powinna być zawartość siarki całkowitej, a określenie dolnych granic frakcji materiału spełniającego wymogi środowiska powinno być dokonywane metodami statystycznymi w oparciu o wyniki eksperymentalnego opróbowania materiału skalnego pozostającego po wzbogaceniu węgla. Zastosowanie zawansowanych metod analizy statystycznej, może ułatwić zaprojektowanie procesów technologicznych, prowadzących do uzyskiwania przemysłowych ilości wysokiej jakości materiału rekultywacyjnego o odpowiednim uziarnieniu. 


\title{
METHODOLOGY OF STATISTICAL STUDY OF THE CHEMICAL COMPOSITION OF BY-PRODUCTS OF COAL MINING TO ASSESS THEIR SUITABILITY AS MATERIALS FOR RECLAMATION
}

\author{
Keywords
}

reclamation, aggregates, mining waste, sulfur, metals and metalloids, statistical analysis

\section{Abstract}

The results of the research presented in earlier works with the participation of the authors (Klojzy-Karczmarczyk et al. 2016a, b, c) indicate the possibility of the use of mining waste from Janina Coal Mine (Upper Silesian Coal Basin, Poland, TAURON Wydobycie S.A.) or products (aggregates) produced on the basis of gangue for technical reclamation. It is essential for this process to obtain a material with low total sulfur, and it has been shown that the best quality parameters are obtained for the material subjected to modification by the rejection of fine fractions. In this work, the lower limit of the material's fraction was determined using statistical analysis, wherein with the predetermined but low probability of error, the content of contaminants (sulfur, as well as other elements) does not exceed the allowable limit (reference value). To solve this task, 3 different statistical methods were used: evaluation of guaranteed contents (the maximum for a given degree of probability) of the polluting components, the results of statistical hypotheses testing and analysis of correlation and regression. The applied statistical methods produce results very proximate to each other. In the presented case study for the Janina coal mine based on the results of a statistically small sample ( $<30$ observations) rock material fraction $>20 \mathrm{~mm}$ may be considered as safe for the purposes of reclamation, and the material fraction $>25 \mathrm{~mm}$ as very safe. It cannot be ruled out, however, that this limit may be reduced to a diameter of $16 \mathrm{~mm}$. The content analysis of 11 elements ( $\mathrm{As}, \mathrm{Cd}, \mathrm{Co}, \mathrm{Cr}, \mathrm{Cu}, \mathrm{Hg}$, $\mathrm{Mo}, \mathrm{Ni}, \mathrm{Pb}, \mathrm{V}, \mathrm{Zn}$ determined as total content in the secondary samples for the fraction $10-200 \mathrm{~mm}$ (the fraction $>200 \mathrm{~mm}$ was not present) showed that they are lower than the allowable limits specified by relevant legal regulations. For this fraction, exceedance of the limit values of sulfur content is, however, highly probable. For this reason, the primary criterion for determining the suitability of the waste material for the purposes of reclamation should be the total sulfur content, and the determination of the lower limits of the material fraction that meets the environmental requirements should be conducted using statistical methods based on the results of experimental sampling of rock remaining after coal preparation. The use of advanced methods of statistical analysis may facilitate the design of technological processes, leading to obtain industrial quantities of high quality, appropriately graded reclamation material. 
